Шатило Олексій Анатолійович кандидат наук з державного управління, докторант кафедри регіональної політики, Київський національний університет ім. Тараса Шевченка, вул. Володимирська, 60, м. Київ, 01033, тел.: (044) 239-33-33, e-mail: alex_shatylo@ukr.net, https://orcid.org/0000-0002-8490-5223

\title{
ДЕРЖАВНА ФІНАНСОВО-КРЕДИТНА ПОЛІТИКА В СИСТЕМІ ЗАБЕЗПЕЧЕННЯ ПРІОРИТЕТІВ ЕКОНОМІЧНОГО РОЗВИТКУ
}

Анотація. В статті досліджено чинні механізми державної фінансовокредитної політики України через призму фінансування пріоритетів економічного розвитку. З'ясовано, що ключовими механізмами фінансової та кредитної підтримки національної економіки є наступні державні програми та фонди, які нами згруповані у дві групи. Перша - це механізми фінансово-кредитного характеру безпосередньої фінансово-кредитної підтримки бізнесу, як то Програма 5-7-9, Програма фінансової підтримки сільгосптоваровиробників, Програма надання кредитів фермерським господарствам. До другої групи віднесено опосередковані механізми, спрямовані на розвиток транспортної інфраструктури (Дорожній фонд), стимулювання регіонального розвитку (Державний фонд регіонального розвитку), розвиток оборонної промисловості (Програма реформування оборонно-промислового комплексу). 3'ясовано, що найбільша частина безпосередньої фінансово-кредитної підтримки вітчизняного бізнесу надійшла в рамках Програми5-7-9, оператором якої є Фонд розвитку підприємництва. Безпосередні обсяги фінансування програми складають 60,4 млрд.грн. за ознакою суми кредитного договору, що поряд з кількістю поданих заявок на участь в програмі - 44,3 тис. одиниць свідчить про актуальність іiі впровадження для вітчизняного бізнесу.

Ще однією масштабною державною програмою, пов'язаною 3 наданням безпосередньої фінансової підтримки суб'єктам господарювання є Державна програма фінансової підтримки сільгосптоваровиробників, адже в поточному році на іiі фінансування передбачено 4,5 млрд.грн. Однак, іiі суттєвим недоліком є ускладнений механізм отримання коштів державної підтримки через Мінагрополітики, оскільки він передбачає, окрім збору та подання численних підтверджуючих документів, ще й подвійне дублювання цього процесу спочатку на регіональному рівні, а потім на рівні Мінагрополітики.

Важливо зазначити, що сумарно обсяги державного фінансування по вказаним програмам перевищують 141 млрд.грн., що складає 10,5\% видаткової частини державного бюджету України.

При цьому слід зауважити, виходячи з наведеного переліку, що в Україні 
достатньо варіативних механізмів фінансово-кредитної підтримки економіки, при цьому важливим завданням $є$ їх детальний аналіз на предмет ефективності та прозорості впровадження, доступності, достатності та недискримінаційності для вітчизняних суб'єктів господарювання.

Ключові слова: фінансово-кредитна політика, економічний розвиток, Програма 5-7-9, Дорожній фонд, Державний фонд регіонального розвитку.

Shatylo Oleksii Anatoliovich PhD in Public Administration, Doctoral Student of Regional Policy Department, Taras Shevchenko National University of Kyiv, Volodymyrivska St., 60, Kyiv, 01033, tel.: (044) 239-33-33, e-mail: alex_shatylo@ukr.net, https://orcid.org/0000-0002-8490-5223

\section{THE PUBLIC FINANCIAL AND CREDIT POLICY AS ELEMENT ECONIMIC POLICY PRIORITIES PROVIDING}

Abstract. The article examines the current mechanisms of Ukraine public financial and credit policy through the prism of economic development priorities financing. It was found the key mechanisms of national economy financial and credit support are the number government programs and funds, which we grouped in two. The first is the direct mechanisms of financial and credit support of business, such as the Program 5-7-9, the Program of financial support of agricultural producers, the Program of granting loans to farms. The second group includes indirect mechanisms aimed at the development of transport infrastructure (Road Fund), stimulation of regional development (State Fund for Regional Development), development of the defense industry (Defense Industry Reform Program). It was found that most of the direct financial and credit support for domestic business came from the Program 5-7-9, which is operated by the Fund for Entrepreneurship Development. Direct funding of the program amounts to UAH 60.4 billion. on the basis of the loan agreement amount, which, along with the number of participation applications - 44.3 thousand units indicates the relevance of its implementation for domestic business. Another large-scale direct financial support provision public program is the State program of financial support for agricultural producers, as this year UAH 4.5 billion is provided for its financing. However, its significant drawback is the complicated mechanism for obtaining state support through the Ministry of Agrarian Policy, as it involves, in addition to collecting and submitting numerous supporting documents, double duplication of this process - first at the regional level and then at the Ministry of Agrarian Policy.

It is important to note that the total amount of public funding for economic development supporting programs exceeds 141 billion UAH, which is $10.5 \%$ of the expenditure part of the Ukraine national budget. As result should be noted, that Ukraine has enough variable mechanisms of financial and credit support to the economy, and an important task is their detailed analysis for efficiency and transparency of 
implementation, accessibility, sufficiency and non-discrimination for domestic businesses.

Keywords: public financial and credit policy, economic development, Program 57-9, Road Fund, Public Fund for Regional Development.

Постановка проблеми. Необхідність розвитку національної економіки $\epsilon$ одним із ключових завдань державного будівництва. В цьому аспекті, державна фінансова та кредитна політика відіграють визначальну роль, адже від доступності фінансово-кредитних ресурсів залежать можливості забезпечення розширеного відтворення в економіці, забезпечення внутрішнього попиту в товарах і послугах, вихід на зовнішні ринки та здобуття належних позицій на глобальному ринку. Окрім того, важливим аспектом фінансової політики держави, що прямо або опосередковано забезпечує подальший розвиток національної економіки $\epsilon$ державне фінансування розвиткових та інфраструктурних програм та конкретних проектів.

Власне, згадана складова фінансової політики наразі набуває значної актуальності в зв'язку із запровадженням протягом останніх років цілої низки державних програм, що зумовлено, в тому числі, успішним розгортанням адміністративно-територіальної реформи, відбудови та розширення критично зношеної інфраструктури та підтримки національного бізнесу у справі подолання негативних наслідків, спричинених глобальною пандемією. Окрім того, не останнє значення відіграють і програмні засади діяльності Президента та уряду, що в своєму комплексі створює чинну фінансову та кредитну політику держави.

Аналіз останніх досліджень та публікацій. Питання формування фінансової політики в Україні знаходиться у фокусі уваги численних дослідників (Дмитренко Г. 2019; Казюк Я. 2020; Олійник Н. 2020; Селіверстова Л., 2018), в працях яких розкриваються елементи формування фінансової політики як в галузевих так i територіальних аспектах, водночас, питання дослідження актуальних механізмів державної фінансово-кредитної політики в аспекті фінансування економічного розвитку держави наразі є недостатньо дослідженим, відтак, визначене за мету нашої публікації.

Виклад основного матеріалу. Основними джерелами фінансування державних та місцевих розвиткових програм $є$ кошти бюджетів усіх рівнів. Водночас, в межах бюджетів кошти спрямовуються на розвиткові проекти шляхом затвердження та виконання загальнодержавних та місцевих програм, що $\epsilon$ ключовим інструментом державної фінансової політики у справі економічного та інфраструктурного розвитку країни. В межах державного бюджету, наразі основним джерелом фінансування розвиткових заходів $є$ так звана, програма «Велике будівництво», яка ініційована чинним Президентом та активно впроваджується вже кілька років поспіль. Дана програма є своєрідним брендом, віртуальною платформою демонстрації досягнень розбудови інфраструктури держави, адже іiі існування не унормоване жодним законодавчим чи підзаконним 
актом, а проекти, які в іï межах впроваджуються, насправді $\epsilon$ елементами реалізації численних державних програм, які реалізуються різними органами, як то Міністерство розвитку громад та територій України, Міністерство інфраструктури України, Міністерство освіти і науки України та ін.

Перелічені органи координують впровадження таких програм як «Дорожній фонд» та «Державний фонд регіонального розвитку», через які фінансуються основна частина інфраструктурних проектів. Власне, структура надходжень Дорожнього фонду є відносно сталою, оскільки вона унормована положеннями чинного законодавства - Законами України «Про внесення змін до Закону України "Про джерела фінансування дорожнього господарства України" щодо удосконалення механізму фінансування дорожньої галузі» [1] та «Про внесення змін до Бюджетного кодексу України щодо удосконалення механізму фінансового забезпечення дорожньої галузі» [2]. Вказаними актами визначено, що джерелами формування коштів державного дорожнього фонду є: акцизний податок з виробленого та/або реалізованого в Україні пального і транспортних засобів (100\% обсягу податкових надходжень); ввізне мито на нафтопродукти i транспортні засоби (100\% обсягу податкових надходжень); акцизний податок 3 ввезених на митну територію України пального і транспортних засобів (100\% обсягу податкових надходжень). Вказані обсяги податків не були сталими 3 моменту їх встановлення у 2018 р., і щороку зростали 3 початкових 50\% на 25 відсоткових пункти, сягнувши вказаних параметрів у 2020 році. Окрім того, до фонду стягуються: плата за проїзд автомобільними дорогами транспортних засобів, вагові або габаритні параметри яких перевищують нормативні; кошти Державного бюджету України, отримані шляхом залучення державою кредитів на розвиток мережі та утримання автомобільних доріг загального користування; плата за проїзд платними автомобільними дорогами; плата за передачу доріг у концесію або в оренду та інші находження.

Так, за підсумками 2020 року, на фінансування заходів ремонту та розбудови транспортної інфраструктури, за рахунок коштів Дорожнього фонду а також коштів інших бюджетних призначень, що передані на проекти розбудови доріг профінансовано порядку 140 млрд.грн. [3], а на 2021 р. на відповідні цілі заплановано спрямувати 132 млрд.грн. [4]. Однак, остання цифра, враховуючи досвід реалізації програми будівництва доріг в 2020 р. може бути не остаточною 3 наступних причин. В 2020 р. планувалося профінансувати значну меншу суму від фактичної, однак, протягом бюджетного року, на відповідні проекти були переспрямовані суттєві ресурси Фонду боротьби з COVID-19 - 33 млрд.грн. [5], 3 яких безпосередні касові видатки на 31 грудня 2020 р. склали 25,7 млрд.грн. [6].

Значно менші, але все ж досить вагомі видатки було профінансовано у 2020 p. через механізм Державного фонду регіонального розвитку (далі - ДФРР), хоча останній, як механізм стимулювання розвитку територій, був створений значно раніше і цей процес був безпосередньо пов'язаний 3 початком адміністративнотериторіальної реформи в Україні у 2014 році. Бюджетним Кодексом України 
визначено, що кошти ДФРР можуть спрямовуватися на різноманітні проекти регіонального розвитку та впровадження інвестиційних програм, а також проектів, спрямованих на співробітництво новостворених об'єднаних територіальних громад, кінцевою метою котрих є сприяння розвиткові регіонів, а в якості економічної складової сприяння розвиткові - створення інфраструктури індустріальних парків. Тим же актом встановлено, що при складанні проекту Державного бюджету України ДФРР передбачається в обсязі не менше 1 відсотка прогнозного обсягу доходів загального фонду Державного бюджету України на відповідний бюджетний період.

Згідно даних реєстру проектів Державного фонду регіонального розвитку, що ведеться Міністерством розвитку громад та територій України, з початку створення фонду, в України здійснюється реалізація 1414 варіативних проектів регіонального розвитку, загальною кошторисною вартістю майже 110 млрд.грн, 3 яких за рахунок коштів ДФРР, тобто державного бюджету планується профінансувати близько 94 млрд.грн. Поряд 3 тим, необхідно зауважити, що 3 вказаних проектів, які реалізовано або знаходяться в реалізації, лише один спрямований на економічний розвиток, кошторисною вартістю 8.6 млн.грн., 3 них кошти ДФРР - менше 4 млн.грн. [7], що $є$ зовсім незначною величиною в структурі видатків ДФРР.

Однак, в загальній множині внесених на розгляд регіональних комісій та Мінрегіону економічних розвиткових проектів обліковується понад 90, 3 очікуваним фінансуванням понад 6 млрд.грн. Відтак, причину недостатньої реалізації проектів, спрямованих на економічний розвиток слід шукати не в браці місцевих ініціатив, а в існуючому порядку відбору проектів до реалізації, що розглядалося нами раніше [8].

Поряд 3 програмами та проектами «Великого будівництва», в Україні реалізуються й інші механізми фінансування пріоритетів економічного розвитку (табл. 1), серед яких чільне місце займає урядова програма доступного кредитування, яка повсюдною мовою іменується «Програма 5-7-9». Порядок реалізації вказаної програми визначений положеннями Постанови КМУ «Про надання фінансової державної підтримки», яким визначено, що програма поширюється на суб'єктів малого та середнього підприємництва, без дискримінації по сфері діяльності. Ключовими критеріями відповідності учасників програми ii вимогам є: зареєстрованість на території України згідно чинного законодавства як суб'єкта підприємництва; не бути отримувачем державної фінансової допомоги протягом попередніх трьох років у визначених сумах залежно від виду такої підтримки [9]. Оператором програми є Фонд розвитку підприємництва, діяльність якого координується через Міністерство фінансів України. Якщо проаналізувати безпосередні обсяги фінансування програми, то вони наразі є досить значними і складають 60,4 млрд.грн. за ознакою суми кредитного договору, що поряд 3 кількістю поданих заявок на участь в програмі - 44,3 тис. одиниць [10] свідчить про актуальність іiі 
впровадження для вітчизняного бізнесу. На компенсацію різниці в кредитних ставках та інших заходів програми, в державному бюджеті на 2021 р. заплановані видатки в розмірі 2 млрд.грн.

Додатковим підтвердженням вагомості реалізації «Програми 5-7-9» для вітчизняного бізнесу $\epsilon$ порівняння частки запозичень, здійснених в рамках програми, із загальним кредитним портфелем суб'єктів малого (в тому числі мікро підприємництва) i середнього підприємництва в Україні - за даними Національного банку, він наростаючим підсумком складає близько 400 млрд.грн. [11] (по кредитному портфелю коротко- і середньострокових кредитів), таким чином становлячи вагу кредитування по програмі у межах 15\% від загальної кількості виданих цільових кредитів, а якщо порівнювати лише в межах короткострокового кредитування - до 1 року, що може розглядатися як більш коректне порівняння в зв’язку $з$ тим, що «Програма 5-7-9» власне реалізується трохи більше року, а в середньострокові кредити входять ті, що були видані протягом останніх п'яти років, то частка кредитів програми складатиме вже 23\%, тобто майже четверту частину.

Таблиия 1

Державні програми підтримки економічного розвитку

\begin{tabular}{|c|c|c|}
\hline Назва програми/фонду & Напрями впровадження & $\begin{array}{c}\text { Планові } \\
\text { видатки } \\
\text { на } 2021 \text { рік, } \\
\text { млрд.грн. }\end{array}$ \\
\hline Державний дорожній фонд & $\begin{array}{l}\text { Реконструкція існуючої транспортної мережі } \\
\text { та будівництво нових об’єктів транспортної } \\
\text { інфраструктури }\end{array}$ & 132,000 \\
\hline $\begin{array}{l}\text { Державний фонд } \\
\text { регіонального розвитку }\end{array}$ & $\begin{array}{l}\text { Впровадження проектів регіонального } \\
\text { розвитку, спрямованих на економічних } \\
\text { розвиток територій, розвиток спортивної, } \\
\text { освітньої, медичної інфраструктури }\end{array}$ & 4,500 \\
\hline «Програма 5-7-9» & $\begin{array}{l}\text { Підтримка інвестиційних проектів МСП; } \\
\text { Підтримка ліквідності МСП; } \\
\text { Рефінансування МСП за раніше } \\
\text { оформленими кредитами }\end{array}$ & 2,000 \\
\hline $\begin{array}{l}\text { Фінансова підтримка } \\
\text { сільгосптоваровиробників }\end{array}$ & $\begin{array}{l}\text { Залучення та здешевлення кредитів для } \\
\text { аграрного сектору; } \\
\text { Стимулювання розвитку с.-г. } \\
\text { товаровиробників; } \\
\text { Оновлення машинно-тракторного парку с.-г. } \\
\text { товаровиробників; } \\
\text { Стимулювання розвитку сімейних } \\
\text { господарств }\end{array}$ & 4,500 \\
\hline $\begin{array}{l}\text { Виконання зобов’язань } \\
\text { України за участь в } \\
\text { програмі } € \mathrm{C} \text { «COSME» }\end{array}$ & $\begin{array}{l}\text { Доступ МСП до інформації, фінансування, } \\
\text { навчання, консультування МСП; } \\
\text { Покращення доступу до інноваційних та } \\
\text { цифрових інструментів ведення бізнесу }\end{array}$ & 0,025 \\
\hline
\end{tabular}


Наукова діяльність в сфері розвитку АПК

Надання кредитів фермерським господарствам

Реформування обороннопромислового комплексу

\begin{tabular}{l|l} 
НДДКР у сфері розвитку агропромислового \\
виробництва; \\
$\begin{array}{l}\text { Наукові дослідження в сфері переробки } \\
\text { сировини для спиртової галузі }\end{array}$ & 0,147 \\
$\begin{array}{l}\text { Сприяння створенню матеріально-технічної } \\
\text { бази фермерських господарств; } \\
\text { Сприяння нарощуванню продукції } \\
\text { фермерських господарств }\end{array}$ & 0,050 \\
$\begin{array}{l}\text { Проведення наукових розробок в сфері } \\
\text { нових зразків оборонної продукції; } \\
\text { Реорганізація підприємств ОПК та } \\
\text { зміцнення їх матеріально-технічної бази }\end{array}$ & 2,530 \\
\hline
\end{tabular}

НДДКР у сфері розвитку агропромислового $\quad 0,147$ виробництва;

Наукові дослідження в сфері переробки сировини для спиртової галузі

зміцнення їх матеріально-технічної бази

Ще однією масштабною державною програмою, пов'язаною 3 наданням фінансової підтримки суб'єктам господарювання $є$ Державна програма фінансової підтримки сільгосптоваровиробників, розпорядником якої було визначено Мінекономрозвитку, а наразі - Міністерство аграрної політики та продовольства України, адже в поточному році на іiі фінансування передбачено 4,5 млрд.грн. Постановою Кабінету Міністрів України «Про порядок викоритсання коштів, передбачених у державному бюджеті для фінансової підтримки сільгосптоваровиробників» визначено напрями використання коштів по згаданій програмі, серед яких: підтримку розвитку тваринництва та переробки сільськогосподарської продукції; фінансову підтримку розвитку фермерських господарств; часткову компенсацію вартості сільськогосподарської техніки та обладнання вітчизняного виробництва; фінансову підтримку заходів в агропромисловому комплексі шляхом здешевлення кредитів; фінансову підтримку розвитку садівництва, виноградарства та хмелярства; надання сімейним фермерським господарствам додаткової фінансової підтримки; державну підтримку страхування сільськогосподарської продукції; відшкодовування втрат від пошкодження посівів сільськогосподарських культур; державну підтримку сільськогосподарських товаровиробників, які використовують меліоровані землі; державну підтримку виробників органічної сільськогосподарської продукції; державну підтримку виробників картоплі; державну підтримку сільськогосподарських товаровиробників шляхом виділення бюджетних субсидій з розрахунку на одиницю оброблюваних угідь.

Аналізуючи вказані напрями детальніше, можна виявити, що частина 3 них, а саме - заходи зі здешевлення кредитів, повторює напрями державної фінансової підтримки, передбачені Програмою 5-7-9, відтак, доречніше, на нашу думку, було б перенести відповідні асигнування до останньої разом зі зміною розпорядника. Додатковим аргументом стосовно зміни розпорядника коштів програми, під егідою якою здійснюватимуться певні заходи підтримки сільгосптоваровиробників, є ускладнений механізм отримання коштів державної 
підтримки через Мінагрополітики, адже він передбачає, окрім збору та подання численних підтверджуючих документів, ще й подвійне дублювання цього процесу - спочатку на регіональному рівні, а потім на рівні Мінагрополітики. Більше того, враховуючи необхідність верифікації за підсумками польових обстежень по окремих напрямах програм сільгосппідтримки, здійснених або відповідною регіональною комісією, утвореною обласним підрозділом місцевої державної адміністрації з питань аграрного розвитку, або представниками Мінагрополітики, закладає корупційну складову в механізм використання публічних коштів.

Крайньою, на даний час, кошторисом понад 2,5 млрд.грн., масштабною програмою фінансової підтримки суб'єктів національної економіки є Програма реформування оборонно-промислового комплексу, суб'єктом реалізації якої $\epsilon$ Міністерство з питань стратегічних галузей промисловості. Вказаною програмою передбачено спрямування коштів на наступні напрями: виконання науководослідних робіт з розробки засобів та технологій; технічне переоснащення та реконструкція діючих виробництв; нарощування наявних виробничих потужностей тощо. Власне, вказана програма спрямована, перш за все, на розвиток лише окремої, специфічної складової національної економіки підприємств, установ та організацій оборонно-промислового комплексу, однак, на нашу думку, виходячи 3 напрямів використання коштів за цією програмою, за умови ефективного iї впровадження, що оцінити наразі неможливо, адже програма новітня і не має своєї попередньої історії впровадження, може справити значний вплив на розвиток промисловості України.

Висновки. Підсумовуючи викладене, можна констатувати, що в Україні запроваджено варіативні механізми фінансової та кредитної підтримки національної економіки, які реалізуються як через безпосередні програми фінансово-кредитного характеру, як то Програма 5-7-9, Програма фінансової підтримки сільгосптоваровиробників, Програма надання кредитів фермерським господарствам, так і через опосередковані механізми, спрямовані на розвиток транспортної інфраструктури (Дорожній фонд), стимулювання регіонального розвитку (Державний фонд регіонального розвитку), розвиток оборонної промисловості (Програма реформування оборонно-промислового комплексу). Важливо зазначити, що сумарно обсяги державного фінансування по вказаним програмам перевищують 141 млрд.грн., що складає 10,5\% видаткової частини державного бюджету України.

При цьому слід зауважити, виходячи з наведеного переліку, що в Україні достатньо варіативних механізмів фінансово-кредитної підтримки економіки, при цьому важливим завданням $є$ їх детальний аналіз на предмет ефективності та прозорості впровадження, доступності, достатності та недискримінаційності для вітчизняних суб'єктів господарювання, що може бути перспективним напрямом подальших наукових розвідок. 


\section{Лimepamypa:}

1. Про джерела фінансування дорожнього господарства України : Закон України від 2 лип. 2020 р. Голос України. 1991. 4 жовт.

2. Про внесення змін до Бюджетного кодексу України щодо удосконалення механізму фінансового забезпечення дорожньої галузі : Закон України від 17 лист. 2016 р. № 98. Офіційний вісник України. 2016. 20 груд.

3. Про державний бюджет України на 2020 рік : Закон України від 10 груд. 2020 р. № 99. Офіційний вісник України. 2019. 24 груд.

4. Про державний бюджет України на 2021 рік : Закон України від 5 серп. 2021 р. № 3. Офіційний вісник України. 2021. 12 січ.

5. Про внесення зміни до статті 28 Закону України "Про Державний бюджет України на 2020 рік" : Закон України від 18 черв. 2020 р. № 102. Офіційний вісник України. 2020. 24 черв.

6. Фонд боротьби 3 гострою респіраторною хворобою COVID-19, спричиненою коронавірусом SARS-CoV-2, та ii наслідками Міністерство фінансів України : веб-сайт. URL: https://mof.gov.ua/uk/data_and_analytics-433 (Дата звернення: 9.09.2021).

7. Державний фонд регіонального розвитку Міністерство розвитку громад та територій України : веб-сайт. URL: http://www. dfrr.minregion.gov.ua/Projects-list (Дата звернення: 9.09.2021).

8. Казюк Я.М., Шатило О.А. Планування територіального розвитку як елемент забезпечення національних інтересів України. № 22 Публічне управління та адміністрування в Україні. 2021.

9. Про надання фінансової державної підтримки : Постанова Кабінету Міністрів України від 24 січ. 2020 р. № 12. Офіційний вісник України. 2020. 14 лют.

10. Структура кредитного портфелю у розрізі видів економічної діяльності Фонд розвитку підприємництва : веб-сайт. URL: https://bdf.gov.ua/5-7-930-08-2021.pdf (Дата звернення: 9.09.2021).

11. Кредити, надані депозитними корпораціями нефінансовим корпораціям, за розміром суб'єкта господарювання та строками погашення Національний банк України : веб-сайт. URL: https://bank.gov.ua/ua/statistic/sector-financial/data-sector-financial (Дата звернення: 9.09.2021).

\section{References:}

1. Zakon Ukrainy "Pro dzherela finansuvannya dorozhn'ogo gospodarstva Ukrayiny" : vid 2 lypnia 2020 roku, № 677-IX [Law of Ukraine "About sources of financing of road economy of Ukraine" from July 2, 2020, № 677-IX]. (n.d.). zakon.rada.gov.ua. Retrieved from https://zakon.rada.gov.ua/laws/ show/677-9 [in Ukrainian].

2. Zakon Ukrainy "Pro vnesennya zmin do Byudzhetnoho kodeksu Ukrayiny shchodo udoskonalennya mekhanizmu finansovoho zabezpechennya dorozhn'oyi haluzi” : vid 17 lyst. 2016 roku, № 1763-VIII [Law of Ukraine "About modification of the Budget code of Ukraine concerning improvement of the mechanism of financial maintenance of road branch” from Nov. 17, 2016, № 1763VIII]. (n.d.). zakon.rada.gov.ua. Retrieved from https://zakon.rada.gov.ua/laws/show/1763-8 [in Ukrainian].

3. Zakon Ukrainy "Pro derzhavnyy byudzhet Ukrayiny na 2020 rik" : vid 10 grud. 2020 roku, № 294-IX [Law of Ukraine “About the state budget of Ukraine for 2020” from Des. 10, 2020, № 294IX]. (n.d.). zakon.rada.gov.ua. Retrieved from https://zakon.rada.gov.ua/laws/show/294-9 [in Ukrainian].

4. Zakon Ukrainy "Pro Derzhavnyy byudzhet Ukrayiny na 2021 rik" : vid 5 serp. 2021 roku, № 1082-IX [Law of Ukraine “About the State Budget of Ukraine for 2021” from Jul. 5, 2021, № 1082-IX]. (n.d.). zakon.rada.gov.ua. Retrieved from https://zakon.rada.gov.ua/laws/show/1082-9 [in Ukrainian].

5. Zakon Ukrainy "Pro vnesennya zminy do statti 28 Zakonu Ukrayiny "Pro Derzhavnyy byudzhet Ukrayiny na 2020 rik"” : vid 18 cherv. 2020 roku, № 726-IX [Law of Ukraine “About modification of article 28 of the Law of Ukraine "About the State budget of Ukraine for 2020" " from Jun. 18, 2020, № 726-IX]. (n.d.). zakon.rada.gov.ua. Retrieved from https://zakon.rada.gov.ua/laws/ show/726-9 [in Ukrainian]. 
6. Ministry finance of Ukraine (2021), Fund for the Control of Acute Respiratory Disease COVID-19 Caused by SARS-CoV-2 Coronavirus and Its Consequences, available at: https://mof.gov.ua/uk/data_and_analytics-433 (Accessed 9 September 2021).

7. Ministry for Communities and Territory Development of Ukraine (2021) State Fund for Regional Development, available at: http://www. dfrr.minregion.gov.ua/Projects-list (Accessed 9 September 2021).

8. Kazuk Y., Shatylo O. (2021) Planuvannya terytorial'noho rozvytku yak element zabezpechennya natsional'nykhinteresivUkrayiny [Territorial development planning as an element of ensuring the national interests of Ukraine]. Public administration in Ukraine [in Ukrainian].

9. Decret Cabinet Ministry of Ukraine "Pro nadannya finansovoyi derzhavnoyi pidtrymky" : vid 24 sich.2020 roku, № 28-2020-ח [Law of Ukraine “On providing financial statesupport" from Jan. 24, 2020, № 28-2020-п]. (n.d.). zakon.rada.gov.ua. Retrieved from https://zakon.rada.gov.ua/laws/ show/28-2020-п [in Ukrainian].

10.Entrepreneurship Development Fund (2021) The structure of the loan portfolio in terms of economic activities, available at: https://bdf.gov.ua/5-7-930-08-2021.pdf (Accessed 9 September 2021).

11. National Bank of Ukraine (2021) Loans granted by deposit-taking corporations to nonfinancial corporations, by size of business entity and maturity, available at: https://bank.gov.ua/ua/statistic/sector-financial/data-sector-financial (Accessed 9 September 2021). 